ANUVA Volume 2 (2): 205-212, 2018

Copyright @2018, ISSN: 2598-3040 online

Available Online at: http://ejournal.undip.ac.id/index.php/anuva

\title{
Peran Perpustakaan dalam Mewujudkan Budaya Informasi Masyarakat
}

\author{
Lydia Christiani $^{1 *}$ \\ ${ }^{1}$ Program Studi Ilmu Perpustakaan, Fakultas Ilmu Budaya, Universitas Diponegoro, \\ Jl. Prof. Soedarto, SH, Kampus Undip Tembalang, Semarang, Indonesia 50275
}

${ }^{*}$ Korespondensi: lydia.christiani@undip.ac.id

\begin{abstract}
[Title: The Role of Library in Making the Culture of Information Society] Knowledge is power. This is what underlies the development of civilization of mankind into an era based on the power of information, known as the information age. This era demands changes in the structure of society, both in the historical, economic, political, and socio-cultural dimension that is oriented towards the creation, distribution and utilization of information. The community structure is known as the information society, a concept of society that performs information management activities as a central activity undertaken to actualize oneself in life. The structure of this new society, gave birth to various levels in its social structure that gave rise to the information-rich and information-poor society. The two groups of information society is separated by the gap information is wide enough, this condition that eventually spur library as a non-profit information institutions to stand as mediators and seeks to bridge the gap information, so that information can be spread more evenly and can be utilized by every individual in information society to actualize themselves, so that in the end the library is able to encourage the realization of a healthy information culture for the whole society.
\end{abstract}

Keywords: Information Society, Information Culture, Information Age, Role of Library

\begin{abstract}
Abstrak
Pengetahuan adalah kekuatan. Hal inilah yang mendasari perkembangan peradaban umat manusia memasuki sebuah era yang berdasar pada kekuatan informasi, yang dikenal dengan istilah era informasi. Era ini menuntut adanya berbagai perubahan dalam struktur masyarakat, baik dalam dimensi historis, ekonomis, politis, maupun sosial budaya yang berorientasi pada kegiatan mengkreasikan, mendistribusi, dan memanfaatkan informasi. Struktur masyarakat tersebut dikenal dengan istilah masyarakat informasi, sebuah konsep masyarakat yang melakukan kegiatan pengelolaan informasi sebagai kegiatan sentral yang dilakukan untuk mengaktualisasikan diri dalam kehidupan. Struktur masyarakat baru ini, melahirkan berbagai tingkatan dalam struktur kemasyarakatannya yang melahirkan golongan masyarakat kaya informasi dan masyarakat miskin informasi. Kedua golongan masyarakat informasi ini dipisahkan oleh jurang informasi yang cukup lebar, kondisi inilah yang akhirnya memacu perpustakaan sebagai lembaga informasi non profit untuk berdiri sebagai penengah dan berupaya untuk menjembatani jurang informasi tersebut, agar informasi dapat tersebar dengan lebih merata dan dapat dimanfaatkan oleh setiap individu dalam masyarakat informasi untuk mengaktualisasikan diri, sehingga pada akhirnya perpustakaan mampu mendorong terwujudnya budaya informasi yang sehat bagi seluruh masyarakat.
\end{abstract}

Kata Kunci: Masyarakat Informasi, Budaya Informasi, Era Informasi, Peran Perpustakaan

\section{Pendahuluan}

Masyarakat informasi adalah sebuah istilah yang mulai muncul di era 80-an, dimana negaranegara maju mulai meninggalkan konsep masyarakat industri sebagai akibat dari revolusi industri dan 
bergerak menuju konsep masyarakat baru yang disebut dengan masyarakat informasi. Istilah masyarakat informasi muncul sebagai label dari adanya sebuah gejala masyarakat yang dalam kehidupannya sangat bergantung pada informasi, yangmana gejala tersebut muncul sebagai akibat dari adanya revolusi komunikasi yang ditandai dengan adanya penemuan mesin cetak dan komputer (Webster, 1995).

Adanya gejala masyarakat informasi tersebut membawa perubahan yang signifikan dalam struktur masyarakat, baik dari segi politik, ekonomi, hingga sosial budaya. Semakin mudahnya penyebaran informasi membuat masyarakat bergerak semakin cepat. Loncatan kondisi masyarakat dari masyarakat industri menuju masyarakat informasi tentu saja tidak berjalan dengan mulus, terdapat berbagai masalah yang harus dihadapi. Salah satu hal yang menjadi masalah adalah timbulnya ledakan informasi, dimana setiap orang dapat mengakses informasi secara terbuka, cepat, dan tepat. Ledakan informasi ini memungkinkan adanya monopoli informasi yang dilakukan oleh seseorang maupun sekelompok orang. Hal tersebut pada akhirnya menimbulkan adanya golongan orang-orang yang kaya informasi dan orang-orang yang miskin informasi. Kondisi inilah yang mendorong perpustakaan, sebagai salah satu lembaga informasi, untuk merevitalisasi perannya sebagai penengah penyebaran informasi agar informasi tidak menjadi monopoli perorangan atau sekelompok orang saja.

\section{Metode Penelitian}

Penulisan artikel ini menggunakan metode analisis deskriptif dalam pembahasannya. yaitu melakukan analisis terhadap sejumlah literatur serta sejumlah sumber data sekunder lainnya. Datadata yang diperoleh dari literatur dan sumber sekunder tersebut dihubungkan dan dibandingkan secara teoritis dengan menggunakan teori-teori yang terkait dengan revitalisasi peran perpustakaan dalam masyarakat informasi. Berdasarkan hasil analisis tersebut akan diketahui potensi perpustakaan sebagai agent of change dalam mendorong terwujudnya budaya informasi di tengah masyarakat. Hasil dari analisis tersebut dapat menggugah pengelola perpustakaan untuk menjalankan peran krusialnya sebagai jembatan informasi bagi masyarakat.

\section{Pembahasan}

\subsection{Perkembangan Istilah Masyarakat Informasi}

Perkembangan peradaban umat manusia terus berkembang, mulai dari masyarakat agraris yang bergerak menuju masyarakat industri, yang kemudian bergerak menuju masyarakat informasi. Hal ini sesuai dengan konsep yang diajukan oleh Alvin Toffler (1980) dalam bukunya "The Third Wave" yang membahas tentang perkembangan peradaban manusia yang dibagi menjadi tiga gelombang yaitu masyarakat agraris (8000 SM-1700), masyarakat industri (1700-1970), dan masyarakat informasi (1970-sekarang). Perubahan perkembangan peradaban tersebut, tentu membawa 
dampak besar bagi struktur tatanan masyarakat. Seperti halnya perubahan yang terjadi dari masyarakat agraris menuju masyarakat industri, yang memberi dampak pada seluruh aspek kehidupan, mulai dari aspek politik, ekonomi, hingga sosial budaya, demikian pula halnya dengan perkembangan peradaban umat manusia dari masyarakat industri menuju masyarakat informasi.

Perubahan struktur dalam masyarakat informasi nampak pada adanya perubahan jumlah pekerja yang bekerja dengan mengolah informasi (white collar workers) yang lebih besar dibandingkan dengan pekerja yang memproduksi barang-barang fisik dan jasa dalam industri (blue collar workers). Dengan kata lain, dalam masyarakat informasi, pengelolaan informasi merupakan kegiatan utama. Jadi, masyarakat informasi adalah suatu istilah yang digunakan untuk menggambarkan sebuah konsep tentang suatu masyarakat yang menciptakan, mendistribusikan, mengeksplorasi, dan mengolah informasi untuk mendukung pengaktualisasian dirinya di dalam kehidupan.

\subsection{Perkembangan Konsep Masyarakat Informasi}

Perubahan struktur masyarakat yang timbul pada era informasi membuat beberapa ahli meneliti perubahan gejala masyarakat tersebut. Jepang dan Amerika Serikat dapat dikatakan sebagai negara pelopor yang memperhatikan industri informasi hingga melahirkan konsep teori masyarakat informasi. Konsep teori dari Jepang dikemukakan oleh Yujiro Hayashi, dalam bukunya yang berjudul Johoka Shakai: Hado no Shakai Kara Sofuto no Shakai e (The information Society: From Hard to Soft Society) yang ditulis pada tahun 1969. Selain itu, konsep teori masyarakat informasi juga diungkapkan oleh Yoneji Masuda dalam bukunya yang berjudul Joho Shakai Nyumon (Introduction to Information Society) yang ditulis pada tahun yang sama dengan karya Yujiro Hayashi (Wiyarsih, 2008).

Teori tentang Masyarakat informasi sendiri mulai berkembang di Amerika Serikat pada tahun 1962 yang ditandai dengan terbitnya buku "The Production and Distribution of Knowledge in The United States" yang ditulis oleh Fritz Machlup. Buku tersebut membahas tentang knowledge industry dari sudut pandang ekonomi (Pendit, 2006). Lebih lanjut Pendit (2006) mengutarakan bahwa teori Machlup berdasarkan pada prinsip interdisipliner, tetapi kelemahannya adalah pada intelectual statelessness. Kelemahan tersebut antara lain adalah:

1. menganggap semua kegiatan sehari-hari seperti berbicara, mendengarkan, dan membaca melibatkan 'state of knowing';

2. terlalu luas sehingga membingungkan;

3. mengklaim bahwa pengukuran dilakukan terhadap produksi dan distribusi pengetahuan, menggunakan teori-teori ekonomi yang tidak pernah dirancang untuk mengukur pengetahuan;

4. menghitung biaya pendidikan dan memasukkan opportunity cost yang meragukan.

Machlup memasukkan 'home education' dalam hitungan (tetapi juga tidak punya metode menghitung yang jelas), sehingga ia juga kesulitan mendapatkan justifikasi tentang apa yang dimaksud dengan 
'new knowledge', yang kemudian membuatnya terjebak oleh keinginannya untuk memperhatikan 'produksi' dan 'distribusi' pengetahuan, padahal data Machlup didominasi oleh data tentang produksi (Pendit, 2006). Berbeda dengan Machlup, Webster (2002) dalam Pendit (2006) mengemukakan bahwa terdapat lima macam definisi tentang masyarakat informasi yang memiliki perhatian khusus tentang lima hal berbeda, yaitu:

1. Teknologi menggunakan kelahiran teknologi baru sebagai sinyal kebangkitan masyarakat baru, terutama di bidang komputasi dan telekomunikasi, sering ditolak karena kurang jelas dalam mengukur kemajuan.

2. Ekonomi terfokus pada "informational activities", proporsi bisnis informasi dalam Gross National Product (GNP), kesulitan dalam definisi data dan cara menghitungnya.

3. Pekerjaan mempelajari struktur tenaga kerja dan kebangkitan service sectors.

4. Spatial menekankan perkembangan networks, seperti information network dan network societies 5. Kultural melihat peningkatan jumlah informasi yang beredar.

Selain teori yang diungkapkan Machlup dan Webster, masih terdapat teori lain yang membahas tentang masyarakat informasi, yaitu teori yang diungkapkan oleh Manuel Castells yang menyoroti tentang network society dikaitkan dengan kehadiran teknologi jaringan komunikasi dan informasi yang hampir sepenuhnya digital, serta keberadaan dan institusionalisasi kelompokkelompok sosial dalam bentuk jaringan sebagai konfigurasi utama. Menurut Castells (1996) dalam Pendit (2006) diungkapkan bahwa sebuah "masyarakat berjaringan" memiliki lima atribut penting yaitu:

1. Berbasis ekonomi kapitalis 'informasional' (rejuvenated form of capitalism);

2. Ekonomi dikelola secara global, tidak terkungkung oleh batas-batas negara atau bangsa;

3. Pengalaman manusia tentang waktu dan ruang dipindahkan ke "timeless time" dan "space of flows";

4. Kekuasaan merupakan fungsi dari akses ke jaringan dan kendali atas aliran. Inklusi dan eksklusi jadi penentu dari berkuasa-tidaknya seseorang;

5. Sumber utama terjadinya konflik dan penentangan (resistence) dalam masyarakat jaringan adalah kontrakdisi antara sifat tak-bertempat (placeless) jaringan dan keberakaran (rootedness) manusia.

Pemikiran Castell inilah yang kemudian merujuk pada konsep network society dalam masyarakat informasi, yang pada akhirnya akan membentuk sebuah kultur yang disebut dengan network culture. Terranova (2004) dalam Pendit (2006) menyatakan bahwa informasi bukanlah semata-mata domain fisik dan juga bukan semata-mata konstruksi sosial. Informasi bukan hanya isi 
dari sebuah tindak komunikasi, bukan sebuah entitas tak-berbentuk (immaterial) yang akan mengambil alih dunia nyata, melainkan sebuah reorientasi bentuk-bentuk kekuasaan dan mode-mode resistensi yang spesifik/unik. Di satu sisi merupakan sebuah resistensi terhadap bentuk-bentuk kekuasaan informasional, karena bentuk-betuk kekuasaan itu mengandung teknik manipulasi dan pengekangan (containment) terhadap virtualitas sosial. Di sisi lain mensyaratkan keterlibatan kolektif dengan potensi dari arus informasi ketika arus ini menggantikan kultur dan membantu manusia melihatnya sebagai tempat bagi sebuah reinvention kehidupan (Pendit, 2006).

\subsection{Dimensi Masyarakat Informasi}

Sebagai sebuah kultur kehidupan, masyarakat informasi memiliki berbagai dimensi, yaitu dimensi historis, dimensi ekonomis, dimensi politis, dan dimensi pemberdayaan sumber daya manusia. Dipandang dari segi historis jelas bahwa munculnya masyarakat informasi disebabkan oleh adanya tuntutan zaman yang telah memasuki babak baru perkembangan peradaban manusia yaitu era informasi, dimana manusia sudah tidak lagi bergantung pada industri manufaktur melainkan bergantung pada informasi, yang pada akhirnya menjadi tonggak knowledge industry (Feather, 1994). Berbicara mengenai dunia industri, tentu saja hal ini telah menyinggung pada dimensi kedua pada masyarakat informasi, yaitu dimensi ekonomis. Dimensi ini menekankan adanya perubahan nilai pandang terhadap informasi sebagai sebuah komoditi yang memiliki nilai jual. Hal ini pada akhirnya memicu timbulnya monopoli akses informasi oleh seseorang maupun sekelompok orang yang sifatnya eksklusif. Perubahan yang terjadi dari segi dimensi ekonomi mendorong timbulnya perubahan pada dimensi politis dalam hal kebijakan penggunaan informasi, baik dari segi akses informasi maupun perlindungan hak cipta bagi para kreator informasi. Perubahan-perubahan yang terjadi tidak mungkin dapat terwujud tanpa adanya sumber daya manusia yang memadai, maka perubahan-perubahan yang terjadi pada dimensi historis, ekonomis, dan politis menuntut adanya perubahan yang signifikan pada dimensi pemberdayaan sumber daya manusia (Feather, 1994).

Pemberdayaan sumber daya manusia dalam masyarakat informasi memiliki cakupan yang luas, berdasarkan definisi masyarakat informasi yang dikemukakan pada Deklarasi World Summit on The Information Society (WSIS) yang dilaksanakan di Genewa pada 10-12 Desember 2003, menyatakan bahwa masyarakat informasi yang berpusat pada masyarakat, inklusif, dan berorientasi pada pembangunan adalah dimana setiap orang dapat membuat, mengakses, memanfaatkan, dan berbagi informasi serta pengetahuan, yang memungkinkan setiap individu, komunitas, dan masyarakat untuk mencapai potensi mereka dalam rangka mengembangkan pembangunan yang terus terpelihara dan mengembangkan kualitas hidup masyarakat, sebagaimana telah dideklarasikan di dalam tujuan dan prinsip-prinsip dari piagam PBB dan menghormati secara penuh serta menguatkan Deklarasi Universal Hak Asasi Manusia (Wiyarsih, 2008). Dari deklarasi tersebut nampak bahwa dalam mewujudkan upaya untuk memberdayakan sumber daya manusia dalam masyarakat informasi diperlukan kebebasan mengakses dan memanfaatkan informasi bagi setiap orang, agar dapat 
menggunakan informasi tersebut untuk mengaktualisasikan dirinya.

Setiap orang memiliki arti tiap-tiap individu, di mana hal tersebut juga berarti bahwa setiap orang memiliki hak yang sama dalam mengolah informasi agar dapat mengaktualisasikan dirinya dalam ruang lingkup masyarakat informasi. Hal ini juga berbicara mengenai konsep semua orang dalam masyarakat informasi, mulai dari Information Proffessional yang bertanggungjawab dalam pendistribusian informasi hingga masyarakat pengguna informasi itu sendiri.

\subsection{Tingkatan Masyarakat Informasi}

Menurut Djunaedi (dalam Wiyarsih, 2008), di dalam masyarakat terdapat tiga tingkatan masyarakat jika dipandang dari aspek informasi. Tingkat pertama adalah masyarakat sadar informasi, yaitu masyarakat yang sudah sadar bahwa informasi diperlukan untuk meningkatkan daya saing untuk maju, misalnya masyarakat petani yang pada saat menjelang panen mencari informasi harga tentang harga-harga jual di berbagai pasar. Tingkat kedua adalah masyarakat kaya informasi, yaitu masyarakat yang sudah cukup banyak mempunyai informasi sehingga cukup mempunyai daya saing (kompetitif), misalnya masyarakat perguruan tinggi, masyarakat dunia usaha (yang bukan usaha kecil dan menengah/UKM). Masyarakat kaya informasi telah mempunyai akses yang memadai ke sumbersumber informasi. Mereka tidak mudah ditipu oleh informasi yang menyesatkan, mereka mampu mengumpulkan informasi yang cukup banyak dengan mudah dan secara perorangan mereka mampu menyeleksi informasi yang benar dan yang kurang benar.

Tingkat ketiga adalah masyarakat berbasis pengetahuan (Knowledge Based Society), yaitu masyarakat kaya informasi yang dalam mengambil keputusan sehari-hari mendasarkan diri pada pengetahuan (Djunaedi dalam Wiyarsih, 2008). Dalam hal ini pengetahuan tersedia secara memadai dan mudah diakses oleh masyarakat. Informasi yang berlimpah mendorong diolahnya informasi tersebut menjadi pengetahuan atau dengan kata lain pengetahuan merupakan tingkatan lebih lanjut dari informasi. Masyarakat berbasis pengetahuan ditunjukkan dengan kemudahan masyarakat mendapatkan pengetahuan. Di luar tiga tingkatan tersebut, terdapat tingkatan masyarakat yang belum mengenal informasi yaitu masyarakat yang belum sadar informasi, contohnya adalah masyarakat pedesaan yang menutup diri dari informasi dari luar. Golongan masyarakat ini belum termasuk dalam ranah masyarakat informasi (Wiyarsih, 2008).

\subsection{Peran Perpustakaan dalam Masyarakat Informasi}

Perubahan-perubahan yang timbul dalam perkembangan peradaban manusia dalam era informasi telah merubah struktur kemasyarakatan dalam kehidupan umat manusia. Era informasi mendorong tumbuhnya masyarakat informasi yang mana turut serta mendorong perubahan-perubahan pada dimensi masyarakat yang terdapat di dalamnya. Perubahan-perubahan tersebut pada akhirnya memunculkan golongan-golongan baru dalam stuktur masyarakat. 
Berkaitan dengan akses informasi, secara garis besar timbul dua golongan dalam masyarakat informasi yaitu masyarakat yang kaya informasi dan masyarakat yang miskin informasi (Feather, 1994). Di sini nampak adanya jurang informasi di dalam struktur masyarakat informasi. Hal ini mendorong perpustakaan untuk merevitalisasi perannya sebagai lembaga informasi untuk lebih berperan aktif dalam menjembatani kesenjangan informasi dalam masyarakat informasi.

Perpustakaan memiliki peran yang penting dalam memberdayakan sumber daya manusia dalam masyarakat informasi agar dapat berjalan selaras dengan percepatan perkembangan era informasi itu sendiri. Perpustakaan harus mampu memaksimalkan upaya untuk memberi kemampuan atau keberdayaan bagi masyarakat untuk mengolah informasi agar dapat dimanfaatkan untuk aktualisasi diri.

Dalam pelaksanaan upaya-upaya pemberdayaan sumber daya manusia dalam masyarakat informasi, perpustakaan berusaha untuk berdiri sebagai posisi penengah di antara golongan masyarakat kaya informasi dan masyarakat miskin informasi. Perpustakaan menjadi penjalin kerjasama antara kedua golongan masyarakat informasi tersebut agar distribusi akses informasi bisa lebih merata. Perpustakaan harus mampu menjalin kerjasama dengan golongan masyarakat kaya informasi untuk berbagi informasi pada golongan masyarakat miskin informasi dan pada saat yang sama mengedukasi golongan masyarakat miskin informasi untuk memperkaya informasi mereka melalui perpustakaan. Dengan demikian, jurang informasi antara golongan masyarakat kaya informasi dan golongan masyarakat miskin informasi tidak semakin luas, hal ini juga memberi dampak positif pada pengurangan monopoli informasi serta perluasan kebebasan akses informasi bagi seluruh lapisan tingkatan masyarakat dalam era informasi.

\section{Simpulan}

Informasi adalah cikal bakal pengetahuan, dan pengetahuan adalah kekuatan. Semangat inilah yang mendasari perubahan peradaban manusia yang terus berkembang. Dari peradaban masyarakat agraris menuju masyarakat industri hingga kini telah memasuki babak baru yaitu era informasi. Era informasi telah merubah tatanan struktur masyarakat beserta seluruh dimensi yang ada di dalamnya. Mulai dari dimensi historis, ekonomis, politis, hingga sosial budaya yang dipelopori oleh pemberdayaan sumber daya manusia dalam masyarakat informasi agar dapat mengaktualisasikan dirinya pada era informasi ini.

Perpustakaan memiliki peran yang krusial dalam pemberdayaan sumber daya manusia dalam masyarakat informasi, terutama bila berbicara tentang adanya jurang informasi yang cukup luas antara golongan masyarakat kaya informasi dan golongan masyarakat miskin informasi. Perpustakaan harus mampu memainkan perannya untuk menjembatani dua golongan masyarakat informasi tersebut agar informasi lebih tersebar merata dan dapat dimanfaatkan setiap orang untuk mengaktualisasikan dirinya dalam masyarakat informasi, sehingga pada akhirnya perpustakaan mampu mendorong adanya budaya informasi dalam masyarakat informasi. 


\section{Daftar Pustaka}

Feather, John. 1994. The Information Society: A Study of Continuity and Change. London: Facet Publishing.

Pendit, Putu Laxman. 2006. Ragam Teori Informasi. Diakses pada tanggal 20 Oktober 2011. Tersedia dalam http://eprints.rclis.org

Toffler, Alvin. 1980. The Third Wave. New York: Bantam Books.

Wiyarsih. 2008. Menuju Masyarakat Informasi. Diakses pada tanggal 20 Oktober 2011. Tersedia dalam http://wiyarsih.staff.ugm.ac.id

Webster, Frank. 1995. Theories of Information Society. London: Routledge. 